\title{
Perancangan Aplikasi Android untuk Kegiatan Tahfizh Alquran Daring Menggunakan Platform Firebase
}

\author{
Abdullah Ardi ${ }^{1}$, Gusti Ridhoni Syahputera ${ }^{2}$, Nurwanto ${ }^{3}$ \\ ${ }^{1,2}$ Politeknik Hasnur; Jl. Brigjen H. Hasan Basri, Handil Bakti Ray V, Kec. Alalak, Kab. Barito \\ Kuala, Telepon 0511-3306886 Fax 0511-3301765 \\ ${ }^{3}$ Universitas Muhammadiyah Ponorogo; Jl. Budi Utomo No.10 Ponorogo, Jawa Timur \\ e-mail: ${ }^{1}$ ardiofchemistry@gmail.com, ${ }^{2}$ syahputera.doni@gmail.com, ${ }^{3}$ nurwanto@ umpo.ac.id
}

\begin{abstract}
Abstrak
Tahfizh Alquran merupakan bentuk kegiatan keagamaan yang memiliki makna untuk menjaga kelestarian dan memelihara Alquran, agar tidak terjadi kegiatan pemalsuan dan perubahan serta dapat menjaga dari hal kelupaan baik secara keseluruhan maupun sebagian. Permasalahan saat ini dengan adanya kondisi pandemi membuat sebagian siswa bahkan masyarakat menjaga jarak dalam melakukan aktivitas sehari-hari, terlebih lagi kegiatan penghafalan Alquran yang dilakukan oleh MTT Miftahul Janah. Aspek ini menyebabkan segala bentuk kegiatan harus dilakukan secara daring mengingat aktivitas kegiatan Tahfiz Alquran harus tetap berjalan, di sisi lain adanya permasalahan ini membuat tidak terjadwal dan terdokumentasi dengan baik segala bentuk kegiatan penghafal Alquran. Aplikasi ini dikembangkan dengan menerapkan model proses dengan alur proses iteratif yakni model iteratiflincremental. Pada model waterfall setiap proses pengembangan dilakukan secara berurutan, yakni dimulai dari komunikasi, perencanaan, pemodelan, konstruksi hingga deployment, sehingga iterasi selanjutnya akan dikerjakan setelah iterasi sebelumnya selesai maupun beriringan dengan iterasi sebelumnya. Hasilnya terciptalah prototipe sistem aplikasi Android berbasis Mobile dengan platform firebase untuk menunjang kegiatan Tahfizh Alquran di MTT Miftahul Janah.
\end{abstract}

Kata kunci : Tahfizh Alquran, Model incremental, Mobile Aplikasi

\begin{abstract}
Tahfizh Alquran is a form of religious activity which has the meaning of preserving and maintaining the Alquran, so that counterfeiting and alteration activities do not occur and can guard against forgetfulness either in whole or in part. The current problem with the pandemic condition has made some students and even the community maintain a distance in carrying out their daily activities, especially the AlQuran memorization activities carried out by MTT Miftahul Janah. This aspect causes all forms of activities to be carried out online considering that the activities of Tahfiz AlQuran activities must continue to run, on the other hand this problem makes it unscheduled and well documented for all forms of Alquran memorization activities. This application was developed by applying a process model with an iterative process flow, namely an iterative / incremental model. In the waterfall model, each development process is carried out sequentially, starting from communication, planning, modeling, construction to deployment, so that the next iteration will be carried out after the previous iteration is complete or in conjunction with the previous iteration. The result was a prototype of a mobile-based Android application system with the firebase platform to support the activities of Tahfizh Alquran at MTT Miftahul Janah.
\end{abstract}


Keywords: Tahfizh Alquran, Incremental Model, Mobile Application

\section{PENDAHULUAN}

Alquran adalah satu-satunya kitab suci yang kesucian dan keasliannya selalu dijamin oleh Allah SWT (Machmud, 2015). Menghafal (tahfizh) Alquran adalah kegiatan yang dimaksudkan untuk menjaga kesucian dan keaslian Alquran dari pemalsuan dan perubahan (Sa'dulloh, 2008). Dalam beberapa tahun terakhir marak bermunculan lembaga-lembaga pendidikan tahfizh Alquran berbentuk sekolah maupun pesantren yang bertujuan memenuhi minat kaum Muslimin untuk menghafal Alquran (Sa'dulloh, 2008). Majelis Taklim dan Tahfiz Miftahul Jannah Kayutangi (MTT Miftahul Jannah) adalah salah satu lembaga pendidikan tahfizh yang terletak di Kota Banjarmasin. MTT Miftahul Jannah beralamat lengkap di Jl. Garuda No. 03, Kecamatan Banjarmasin Utara, Kota Banjarmasin. Peserta program tahfizh Alquran di MTT Miftahul Jannah adalah anak-anak, remaja, dan orang-orang dewasa. Secara rutin pada hari-hari yang dijadwalkan, para peserta dan ustaz/ustazah bertatap muka untuk melaksanakan kegiatan tahfizh.

Di awal tahun 2020, dunia digegerkan dengan kemunculan sebuah virus mematikan bernama Coronavirus. Pandemi virus ini berdampak pada berbagai sektor kehidupan. Untuk memutus penyebaran Coronavirus, lembaga-lembaga pendidikan pun diimbau untuk melakukan pembelajaran jarak jauh (Gunawan \& Yulita, 2020). Dalam rangka memenuhi imbauan pembelajaran jarak jauh, MTT Miftahul Jannah memilih untuk memanfaatkan perangkat Android sebagai sarana kegiatan tahfizh. Android sendiri adalah sistem operasi garapan Google untuk perangkat mobile terutama telepon pintar (smartphone) (Amperianto, 2014).

Selama beberapa bulan terakhir, MTT Miftahul Jannah menggunakan aplikasi perpesanan WhatsApp untuk menjalankan kegiatan tahfizh rutin mereka. WhatsApp sendiri adalah aplikasi perpesanan yang memungkinkan penggunanya bertukar pesan teks, berkas, gambar, dan lain-lain (Nurhalimah, 2019). Para peserta dan ustaz/ustazah MTT Miftahul Jannah menemui berbagai masalah ketika menggunakan WhatsApp pada kegiatan tahfizh mereka. Beberapa kendala tersebut di antaranya adalah sulitnya mengirim tugas-tugas setoran hafalan kepada para peserta, sulitnya mengidentifikasi setoran-setoran hafalan peserta untuk proses pemeriksaan, dan sulitnya mencatat capaian hafalan peserta.

Berdasarkan permasalahan tersebut, diperlukanlah sebuah aplikasi tahfizh Alquran daring (dalam jaringan) berbasis Android sebagai penunjang MTT Miftahul Jannah dalam menjalankan program tahfizh secara jarak jauh. Dalam penelitian ini, dirancanglah prototype aplikasi tahfizh Alquran daring yang dikembangkan menggunakan platform Firebase. Firebase sendiri adalah sebuah platform seluler yang memudahkan pengembang membuat aplikasi berkualitas tinggi dengan cepat (Rozaq, Tolle, \& Fanani, 2018). Aplikasi Android untuk kegiatan tahfizh Alquran daring ini diharapkan dapat yang memberikan kemudahan bagi ustaz/ustazah untuk mengirim dan memeriksa tugas-tugas setoran hafalan serta mencatat capaian setoran hafalan para peserta.

Penelitian terdahulu terkait pengembangan aplikasi tahfizh Alquran pada perangkat mobile antara lain: "Tahfiz Online: Sarana Menghafal Alquran Secara Online" yang mendeskripsikan bagaimana proses pembelajaran tahfizh Alquran dilakukan secara daring menggunakan aplikasi WhatsApp (Rusadi, 2020). "Pengembangan Aplikasi Al-Quran untuk Membantu Hafalan Al-Quran Secara Mandiri Menggunakan Metode Tikrar" yang bertujuan untuk menghasilkan sebuah aplikasi Alquran Tikrar dalam membantu seorang pengguna

Abdullah, et.,al (Perancangan Aplikasi Android untuk Kegiatan Tahfizh Alquran Daring Menggunakan Platform Firebase) 
menghafal Alquran menggunakan metode tikrar (Septiara, Santoso, \& Kharisma, 2019); dan "Pengembangan Aplikasi Smarthafidz Menggunakan Metode Naive Bayes (Studi Kasus Pondok Pesantren Darussalam Sidodadi)" yang bertujuan menghasilkan sebuah aplikasi yang bisa digunakan oleh seorang pengguna untuk menghafal Alquran serta menilai hafalan pengguna menggunakan metode Naive Bayes, pada penelitian ini focus aplikasi yang dihasilkan untuk membantu kegiatan tahfizh Alquran secara mandiri sedangkan pada aplikasi Tahfiz Alquran Daring berfokus agar dapat menjangkau pembelajaran jarak jauh, di sisi ain hanya tedapat satu jenis pengguna ( penghapal ) pada penelitian yang dibuat terdapat tiga jenis pengguna ( penghapal, pengawas hafalan dan penguji hapalan) (Lestari, Susilo, \& Budi, 2020).

\section{METODE PENELITIAN}

Metode yang dipergunakan dalam penelitian ini mengacu pada System Development Life Cycle (SDLC) yang mana bentuk representasi sederhana dari proses software (software prosess) (Sommerville, 2016). Adapun model SDLC yang digunakan pada penelitian ini adalah model pengembangan waterfall dengan alur proses iteratif/incremental, yang mana aktivitasaktivitas dari kegiatan tersebut dimulai dari komunikasi, perencanaan, pemodelan, konstruksi, dan deployment yang dilakukan secara berurutan. Salah satu bentuk keunggulan dalam metode ini adalah mampu menekan biaya produksi yang menjadikannya lebih murah dan lebih fleksibel dalam mengubah ruang dan kebutuhan (requirements).



Gambar 1. Model Pengembangan Incremental

Adapun tahapan dalam pembuatan aplikasi Tahfizh Alquran ini meliputi:

\subsection{Komunikasi}

Pada tahap ini peneliti melakukan proses komunikasi dengan mengamati secara tidak langsung proses kegiatan belajar-mengajar yang di lakukan pada MTT Miftahul Jannah. Proses

Abdullah, et.,al (Perancangan Aplikasi Android untuk Kegiatan Tahfizh Alquran Daring Menggunakan Platform Firebase) 
komunikasi pada dasarnya bertujuan ntuk memahami sasaran stakeholder (klien) sekaligus mengumpulkan informasi kebutuhan (requirements) perangkat lunak.[11]. Dalam hal ini, kegiatan komunikasi dilakukan dalam berbagai bentuk guna mengumpulkan data diantaranya :

a. Melalui mekasnisme wawancara guna mendapatkan informasi mengenai kebutuhan fungsional dan non fungsional terhadap aplikasi Tahfizh Alquran.

b. Memperoleh informasi bagaimana proses kegiatan belajar-mengajar yang dilakukan oleh MTT Miftahul Jannah guna membentuk alur sistem yang akan dibuat.

c. Melalui referensi penelitian sebagai bentuk pengembangan keilmuan.

\subsection{Perencanaan}

Aktivitas perencanaan diperuntukkan untuk menciptakan sebuah rencana proyek (project plan) yang akan membantu pengembang dalam mengerjakan proyek (Pressman \& Maxim, 2015). Salah satu bentuk aktivitas perencanaan yakni pembuatan aplikasi Tahfizh Alquran ialah sebuah jadwal pekerjaan (work schedule).

\subsection{Pemodelan}

Pembuatan model-model dalam rangka memahami permasalahan (yakni kebutuhan/requirements) dan solusi (yakni desain) yang akan dikerjakan dalam rangka menyelesaikan permasalahan tersebut (Pressman \& Maxim, 2015). Dalam penelitian ini, dibuatlah berbagai dokumen, diagram dan gambar-gambar untuk memodelkan berbagai macam aspek dari aplikasi. Adapun alat bantu pengembangan yang dipergunakan dalam proses pemodelan ini adalah sebagai berikut:

a. PlantUML untuk membuat diagram-diagram pemodelan berbasis UML

b. Android Studio sebagai lingkungan pengembangan terpadu (IDE) untuk merancang rencanarencana antarmuka aplikasi

\subsubsection{Identifikasi dan dokumentasi aktor}

Sejumlah aktor telah diidentifikasi pada penelitian ini, antara lain:

a. A10_Siswa adalah aktor konkret yang merepresentasikan seorang siswa/siswi di MTT Miftahul Jannah.

b. A20_Staf adalah aktor abstrak yang merepresentasikan seorang staf/pengurus di MTT Miftahul Jannah. Aktor ini berspesialisasi menjadi:

a. A21_Guru adalah aktor konkret yang merepresentasikan seorang guru (ustaz/ustazah) di MTT Miftahul Jannah.

b. A22_Koordinator adalah aktor konkret yang merepresentasikan seorang koordinator bidang Alquran di MTT Miftahul Jannah.

c. A23_Admin adalah aktor konkret yang merepresentasikan seorang admin di MTT Miftahul Jannah.

\subsubsection{Use case}

Berdasarkan identifikasi dan dokumentasi aktor diatas maka dapat dihasilkan sejumlah use case sebagai berikut : 
a. UC_MembuatTugasBaru adalah use case yang mendeskripsikan proses di mana seorang guru membuat sebuah tugas baru.

b. UC_MelihatDaftarTugas adalah use case yang mendeskripsikan proses di mana seorang guru atau siswa melihat daftar tugas.

c. UC_MelihatRincianTugas adalah use case yang mendeskripsikan proses di mana seorang siswa atau guru melihat rincian.

d. UC_MenyetorTugas adalah use case yang mendeskripsikan proses di mana seorang siswa mengerjakan sebuah tugas dan menyetorkannya kepada guru.

e. UC_MelihatDaftarSetoran adalah use case yang mendeskripsikan proses di mana seorang guru melihat daftar setoran.

\subsubsection{Use Case Diagram}

Pada dasarnya Use Case Diagram diperuntukan untuk menggambarkan apa saja yang akan dilakukan oleh aktor atau pengguna pada aplikasi Tahfiz Alquran di MTT Miftahul Jannah. Use case ini dibentuk berdasarkan pada analisis kebutuhan yang diperoleh berdasarkan tahapan komunikasi. Terdapat 3 aktor (pengguna) yakni Koordinator, Guru dan Siswa, dimana masingmasing aktor memiliki hak akses yang berbeda seperti yang di tunjukkan pada gambar 2. Use Case Diagram UCD_Penugasan, dan gambar 3. Use Case Diagram UCD_Pelaporan. 


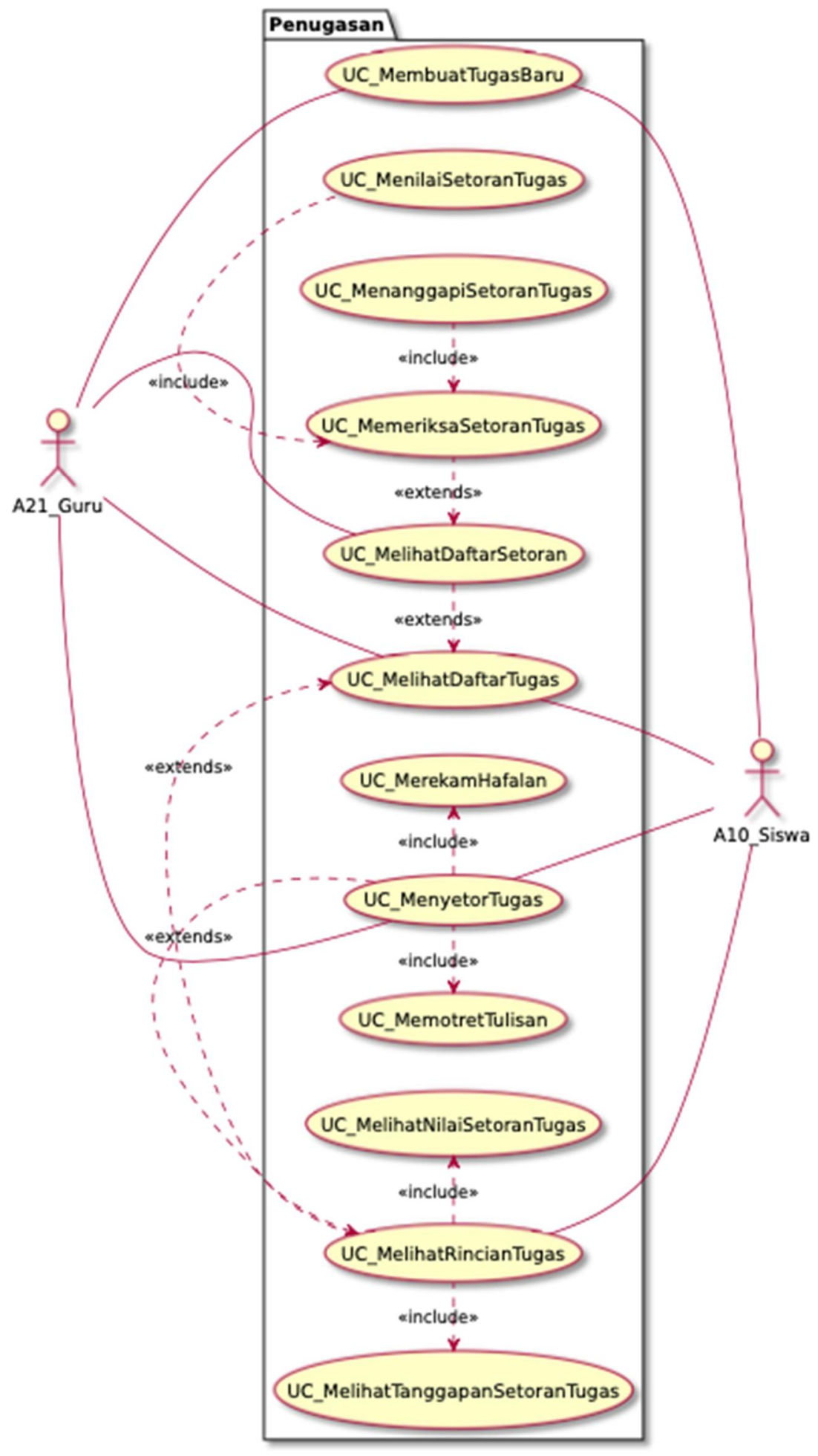

Gambar 2. Use Case Diagram UCD_Penugasan

Abdullah, et.,al (Perancangan Aplikasi Android untuk Kegiatan Tahfizh Alquran Daring Menggunakan Platform Firebase) 


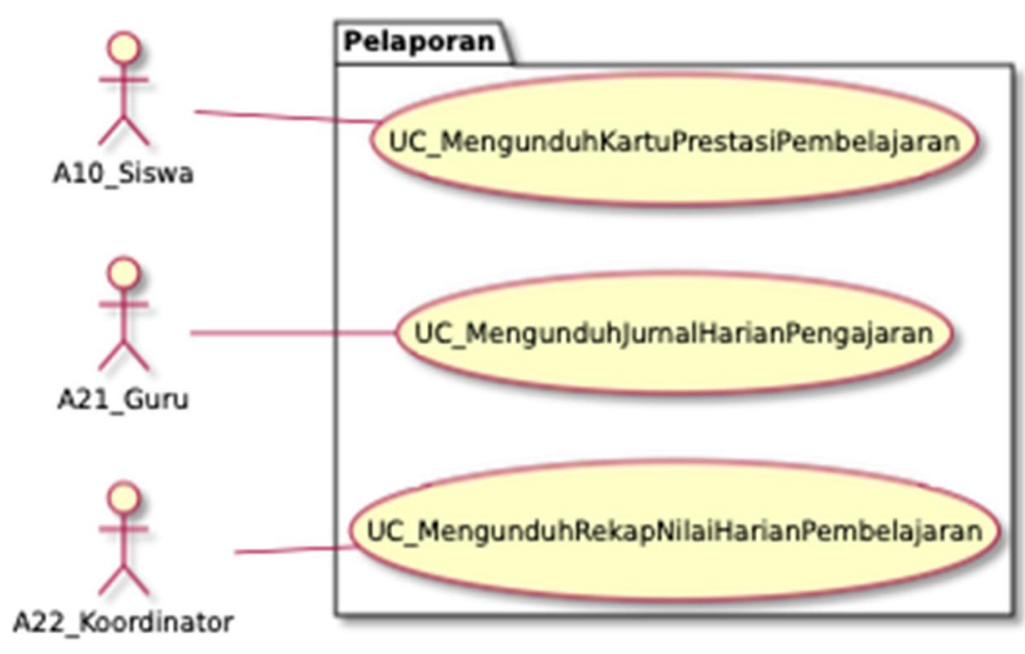

Gambar 3. Use Case Diagram UCD_Pelaporan

\subsubsection{Class Diagram}

Berdasarkan analisis pada use case dan deskripsi aktor yang dibuat, diperoleh 8 kelas entitas diantaranya: Siswa, Staf, Guru, Koordinator, Admin, Halaqah, Tugas dan Setoran Tugas, yang ditunjukkan pada gambar 4. Class Diagram Aplikasi Tahfizh Daring. 


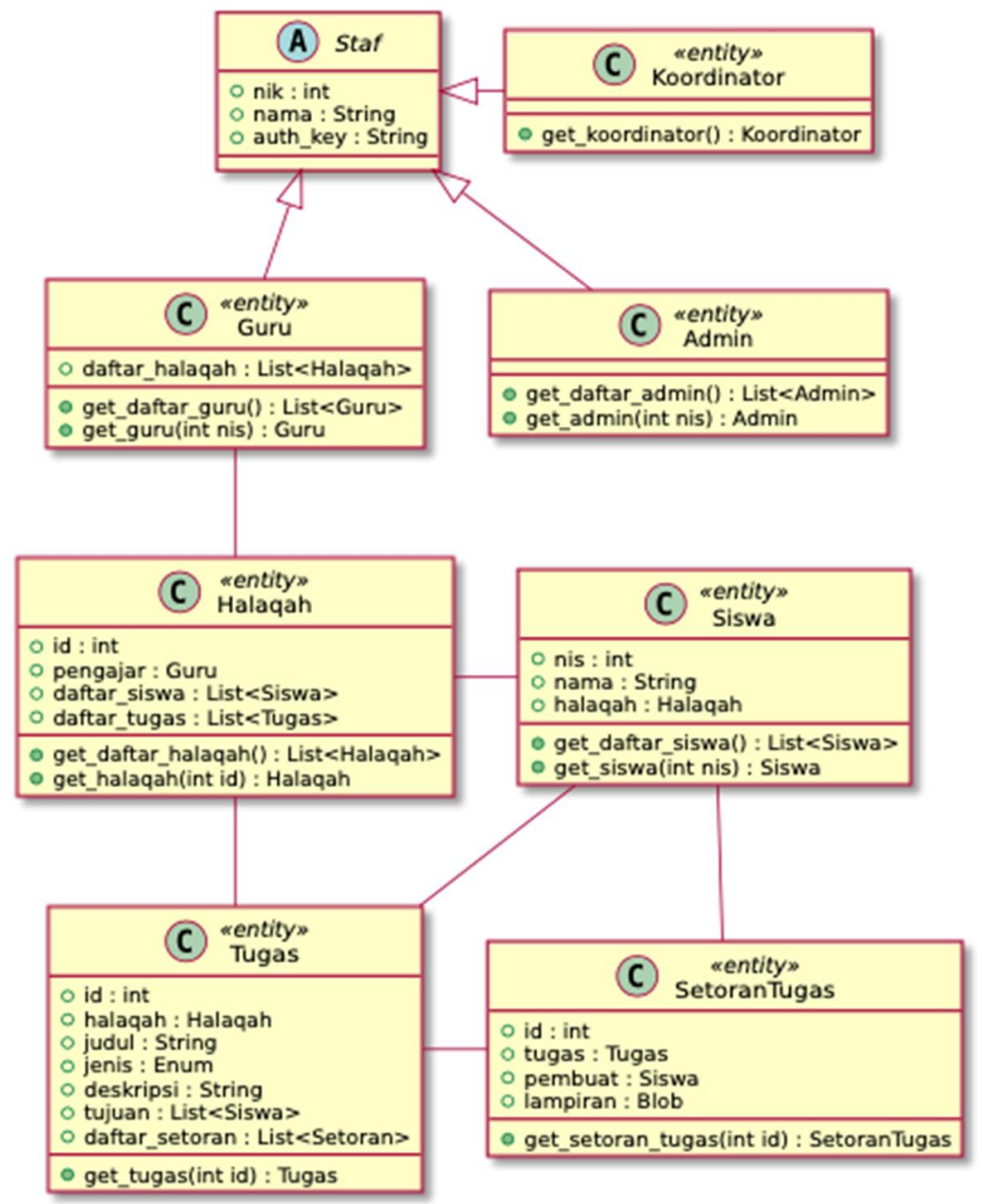

Gambar 4. Class Diagram Aplikasi Tahfizh Daring

\subsection{Konstruksi}

Pendekatan yang digunakan pada aktivitas konstruksi (construction) dalam penelitian ini adalah Test-Driven Development, di mana unit test dibuat lebih dahulu sebelum penulisan kode program (coding) dilakukan. Adapun alat bantu pengembangan yang digunakan dalam aktivitas konstruksi pada penelitian ini adalah sebagai berikut:

a. Android Studio sebagai lingkungan pengembangan terpadu (IDE) untuk pembangunan aplikasi sisi klien.

b. Gradle untuk mengelola pustaka dependensi, pembangunan (building) artifak executable, dan pengujian unit testing aplikasi sisi klien.

\subsection{Deployment}

Deployment merupakan aktivitas penyerahan perangkat lunak (baik dalam bentuk komplet maupun parsial) kepada klien yang selanjutnya akan mengevaluasi perangkat lunak dan memberikan tanggapan berdasarkan hasil evaluasi yang dilakukan (Pressman \& Maxim, 2015). Alat bantu pengembangan yang digunakan pada aktivitas deployment dalam penelitian ini

Abdullah, et.,al (Perancangan Aplikasi Android untuk Kegiatan Tahfizh Alquran Daring Menggunakan Platform Firebase) 
adalah Gitlab CI/CD. Gitlab CI/CD dimanfaatkan untuk otomatisasi pembangunan (building) artefak executable dan proses pembaruan aplikasi.

\section{HASIL DAN PEMBAHASAN}

Hasil dari penelitian ini adalah pelaksanaan kegiatan Penghafalan Alquran/ Tahfizh Alquran dapat terintegrasi dengan menerapkan aplikasi Tahfizh Alquran Daring menggunakan Platform Firebase. Aktor, user, atau pengguna dalam penerapan sistem ini terdiri dari Guru (ustaz/ustazah), Koordinator, dan Siswa. Dengan kondisi pandemi Covid-19 sekarang ini, siswa tidak perlu datang tatap muka untuk melaksanakan kegiatan Penghafalan Alquran, akan ada sistem yang akan selalu menginformasikan kapan siswa harus menyetorkan hafalan atau guru memeriksa dan memberikan tugas. Aplikasi Tahfizh Alquran Daring menggunakan Platform Firebase diharapkan mampu menyerap banyak siswa tidak hanya di daerah kota Banjarmasin, namun bisa menampung banyak calon Tahfizh Alquran di luar kota Banjarmasin.

\subsection{Guru/Admin Tahfizh Alquran Daring}

a. Halaman login menampilkan form login, para guru/admin harus memasukkan data username dan password masing-masing. Data tersebut sudah terdaftar di akun database.

b. Halaman Dasboard guru/admin berisikan berbagai menu kegiatan salah satunya adalah membuat tugas untuk hafalan, yang di tunjukkan pada gambar 5. Halaman Membuat Tugas

\section{Buat Tugas}

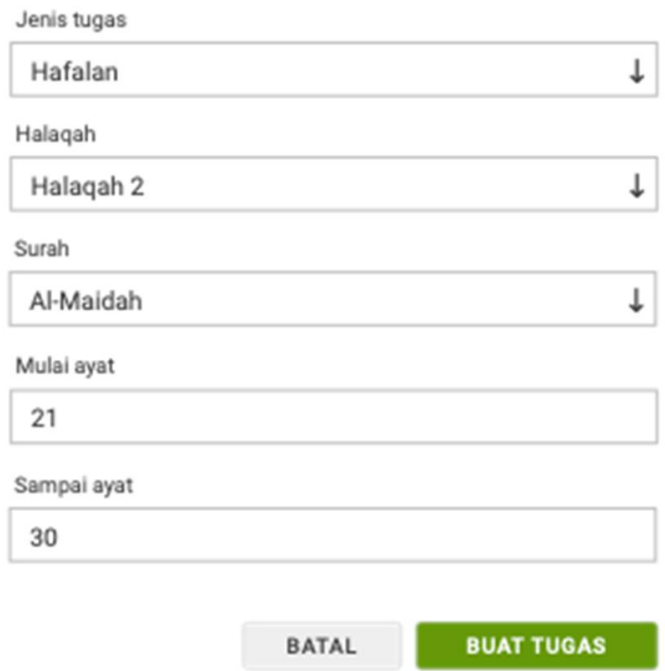

Gambar 5. Halaman Membuat Tugas

c. Tampilan lain yang menggambarkan dasboard dari Guru/ Admin ialah halaman melihat daftar tugas dan daftar setoran dari siswa yang telah mengirimkan tugasnya, yang mana tugas tersebut harus segera di periksa. Masing-masing guru akan mampu memberikan 
banyak tugas sesuai dengan tingkatan dari siswa tersebut, hal ini terlihat pada gambar 6 . Halaman Daftar tugas dan Rincian Tugas

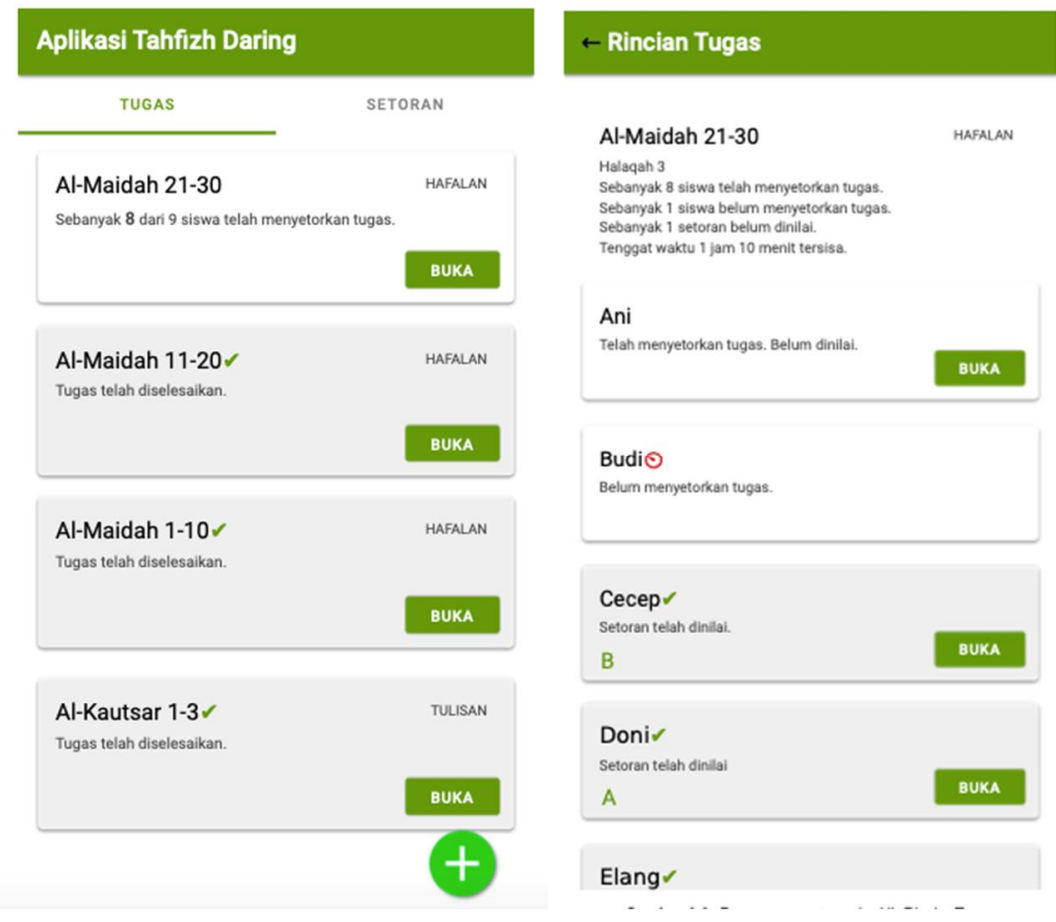

Gambar 6. Halaman Daftar Tugas dan Rincian Tugas

d. Halaman Logout untuk Halaman Guru.

\subsection{Siswa}

a. Halaman Beranda tidak lah berbeda antara guru dengan siswa, masing masing user memiliki akses login dengan menggunakan username dan password yang sudah ditentukan

b. Halaman Beranda pada Aplikasi Tahfizh Alquran Daring untuk user/siswa, di mana berisikan berbagai informasi terkait pelaksanaan kegiatan Tahfiz Alquran seperti : halaman tugas, halaman untuk setoran tugas (baik mengunakan video, maupun menggunakan voice/suara), seperti yang di tunjukkan pada Gambar 7. Beranda Aplikasi Tahfiz Alquran Daring Siswa. Dalam hal ini Aplikasi Tahfizh Alquran Daring memberikan pilihan untuk melakukan pelaporan terkait tugas yang akan di kirimkan Kembali kepada guru. 




Gambar 7. Beranda Aplikasi Tahfiz Alquran Daring Siswa.

c. Halaman Logout untuk keluar dari Aplikasi Tahfiz Alquran Daring Siswa.

\section{KESIMPULAN}

Aplikasi Tahfiz Alquran Daring berbasis Platform Firebase di MTT Miftaul Jannah menggunakan metode waterfall dengan menerapkan skema model incremental. Skema model incremental ini berfokus pada iterasi atau proses kegiatan seperti komunikasi, perencanaan, pemodelan, konstruksi, dan deployment. Penciptaan aplikasi ini mampu mengatasi permasalahan yang dihadapi oleh MTT Miftahul Jannah mengingat kondisi pandemi Covid-19 sekarang ini yang mana memerlukan aplikasi tambahan guna menunjang kegiatan penghafalan Alquran agar dapat berjalan sebagaimana mestinya.

\section{SARAN}

Diharapkan untuk kedepannya pengembangan aplikasi Tahfiz Alquran Daring berbasis Platform Firebase di MTT Miftaul Jannah tidak hanya berfokus pada kegiatan penghafalan saja, namun bisa dikembangkan ke dalam skema yang lebih universal seperti pendaftaran siswa, 
pembayaran SPP. Selain itu diharapkan aplikasi ini dapat diimplementasikan tidak hanya pada perangkat Android.

\section{UCAPAN TERIMA KASIH}

Terima kasih kepada tim Politeknik Hasnur, tim MTT Miftahul Jannah Atas dukungannya dalam permintaan data atas terciptanya Aplikasi Tahfiz Alquran Daring berbasis Platform Firebase di MTT Miftaul Jannah.

\section{DAFTAR PUSTAKA}

[1] Amperianto, T. 2014. Tips Ampuh Android. Jakarta: Elex Media Komputindo.

[2] Gunawan, C. I., \& Yulita. 2020. Anomali Covid-19: Dampak Positif Virus Corona Untuk Dunia. Malang: IRDH Book Publisher.

[3] Lestari, V. F., Susilo, P. H., \& Budi, A. S. 2020. Pengembangan Aplikasi Smarthafidz Menggunakan Metode Naive Bayes (studi Kasus Pondok Pesantren Darussalam Sidodadi). Joutica, 5(2), 381-388.

[4] Machmud, A. 2015. Kisah Penghafal Al-Qur'an. Jakarta: Elex Media Komputindo.

[5] Nurhalimah, S. 2019. Media Sosial Dan Masyarakat Pesisir : Refreksi Pemikiran Mahasiswa Bidikmisi. Sleman: Deepublish.

[6] Pressman, R. S., \& Maxim, B. R. 2015. Software Engineering: A Prctitioner's Approach. New York: McGraw-HIll Education.

[7] Rozaq, A., Tolle, H., \& Fanani, L. 2018. Pembangunan Aplikasi Brawijaya Messenger dengan menggunakan Platform Firebase pada Universitas Brawijaya. Jurnal Pengembangan Teknologi Informasi dan Ilmu Komputer, 667-673.

[8] Rusadi, B. E. 2020. Tahfiz Online: Sarana Menghafal Alquran Secara Online. Jurnal Agama dan Pendidikan Islam, 12(1), 18-33.

[9] Sa'dulloh. 2008. 9 Cara Praktis Menghafal Al-Qur'an. Depok: Gema Insani.

[10] Septiara, A., Santoso, N., \& Kharisma, A. P. (2019). Pengembangan Aplikasi Al-Quran Untuk Membantu Hafalan Al-Quran Secara Mandiri Menggunakan Metode Tikrar. Jurnal Pengembangan Teknologi Informasi dan Ilmu Komputer, 3(3), 2807-2813.

[11] Sommerville, I. 2016. Software Engineering. London: Pearson Education.

\footnotetext{
Abdullah, et.,al (Perancangan Aplikasi Android untuk Kegiatan Tahfizh Alquran Daring Menggunakan Platform Firebase)
} 